\title{
HASIL BELAJAR MATEMATIKA MELALUI METODE POLYA
}

\section{MATHEMATICS LEARNING OUTCOMES THROUGH THE POLYA METHOD}

\author{
Ismawati1), Andi Ika Prasasti Abrar'2), Fitriani Nur'3), Yusuf Tahir ${ }^{4)}$, Ahmad Farham \\ Majid5) \\ 1,2,3,4,5) Fakultas Tarbiyah dan Keguruan Universitas Islam Negeri Alauddin Makassar \\ ismawati@gmail.com ${ }^{1)}$, ika.prasastiabrar@uin-alauddin.ac.id²), fitrianinur@uin-alauddin.ac.id²), \\ yusuf.tahir@uin-alauddin.ac.id ${ }^{4}$, ahmad.farham@uin-alauddin.ac.id ${ }^{5)}$
}

\begin{abstract}
Abstrak
Tujuan penelitian ini adalah untuk mengetahui apakah terdapat perbedaan hasil belajar matematika peserta didik yang diajar menggunakan Metode Polya berbantuan soal cerita dengan tanpa berbantuan soal cerita. Penelitian ini merupakan jenis penelitian experimen semu (Quasi Experimental Design) dengan desain penelitian Non Equivalent Control Group Design. Populasi dalam penelitian ini adalah seluruh peserta didik kelas VIII MTs Negeri Sinjai Utara yang berjumlah 152 peserta didik dengan sampel penelitian berjumlah 61 peserta didik yang berasal dari dua kelas yaitu VIII Dan VIIIC. Pengambilan sampel yang digunakan yaitu teknik Simple Random Sampling. Instrumen yang digunakan berupa tes terdiri dari Pretest dan Posttest. Selanjutnya dianalisis dengan menggunakan statistik deskriptif dan statistik inferensial. Berdasarkan hasil analisis deskriptif diperoleh, nilai rata-rata pretest sebesar 50,77 dan posttest 67,20 dengan peningkatan sebesar 16,43 pada peserta didik yang diajar menggunakan Metode Polya tanpa berbantuan soal cerita. Nilai rata-rata pretest diperoleh 48,97 dan rata-rata posttest sebesar 69,29 dengan peningkatan sebesar 20,32 pada peserta didik yang diajar menggunakan Metode Polya berbantuan soal cerita. Hasil analisis inferensial diperoleh nilai signifikan $=0,318$. Sehingga dapat disimpulkan bahwa tidak terdapat perbedaan rata-rata hasil belajar matematika antara peserta didik yang belajar menggunakan Metode Polya dalam menyelesaikan soal matematika berbantuan soal cerita dengan peserta didik yang belajar menggunakan Metode Polya tanpa berbantuan soal cerita. Hal ini disebabkan karena pada dasarnya Metode Polya memiliki banyak kesamaan dengan metode pemecahan masalah yang lain, yakni mempunyai karakteristik dan sintaks yang menunjang agar pemecahan masalah dari peserta didik dapat meningkat.
\end{abstract}

Kata Kunci: pembelajaran matematika, metode polya, hasil belajar

\begin{abstract}
The purpose of this study was to see whether there were differences in the mathematics learning outcomes of students who used the Polya Method assisted with story problems or without assisted story problems. This research is a quasi-experimental research type (QuasiExperimental Design) with a non-equivalent control group research design. The population in this study were all class VIII MTs Negeri Sinjai Utara students with 152 students with 61 students as research sample of who came from two classes, namely VIII $I_{D}$ and VIIIC. The sampling used was simple random sampling technique. The instrument used was a test consisting of a pretest and posttest. It was then analyzed using descriptive statistics and inferential statistics. Based on the results of the descriptive analysis obtained, the pretest mean score was 50.77 and posttest 67.20, with an increase of 16.43 for students who were taught using the Polya Method without the help of story questions. The average pretest score was 48.97, and the posttest average was 69.29, with an increase of 20.32 for students who were taught using the story-assisted Polya Method. The results of inferential analysis obtained a
\end{abstract}


significant value $=0.318$. So it can be denied that there is no difference in the average student learning outcomes between students who learn to use the Polya method in solving math problems assisted by story problems and students who learn to use the pattern method without the help of story problems. Basically, this is because the Polya Method has many similarities with other problem-solving methods, which have characteristics and syntax that support students' problem-solving.

\section{Keywords: mathematics learning, Polya method, learning outcomes}

How to Cite: Ismawati, Abrar, A. I. P., Nur, F., Tahir, Y., \& Majid, A. F. (2021). Hasil belajar matematika melalui metode Polya. Al asma: Journal of Islamic Education, 3(1), 145-157.

\section{PENDAHULUAN}

Sering kali pendidikan dipandang sebagai tindakan manusia untuk membentuk kepribadian yang menyesuaikan dengan nilai dalam kehidupan masyarakat serta kebudayaan (Hasbullah, 2012). Secara alternatif pendidikan juga dimaksudkan sebagai tindakan sadar yang dikerjakan kerabat, masyarakat, maupun pimpinan dengan cara membimbing, edukasi, serta pelatihan yang diselenggarakan baik lingkup sekolah maupun bukan (Husnidar, 2020). Pendidikan yang diatur dengan dengan baik, teratur, efisien hingga efektif dapat mempercepat laju perjalanan proses pembudayaan berdasarkan inti dari penciptaan kesejahteraan dan pencerdasan masyarakat (Ihsan, 2011). Oleh sebab itu, proses ini menempati posisi penting dari kehidupan bermasyarakat. Bagi masyarakat Indonesia pendidikan pada kondisi sekarang menjadi kebutuhan yang pokok dan wajib ditingkatkan selurus dengan tuntutan tiap perkembangan yang terjadi secara bertahap.

Pelajaran matematika termasuk salah satu pelajaran yang masuk dalam list sarana pengembangan berpikir dengan logis, kritis, dan sistematis. Begitu perlunya pelajaran ini, kurikulum di negara ini bahkan mengatur dimana matematika perlu diajarkan dengan target untuk membekali pelajar dengan keterampilan analitis, logis, sistematis, kreatif, kritis, dan bekerja sama. Artinya, hingga batas yang tidak ditentukan pelajaran matematika perlu dikuasai masyarakat Indonesia, baik berupa penerapan ataupun pola berpikirnya (Retna, 2013). Matematika terus berkembang disebabkan dari proses berpikir, oleh sebab itu logika ialah landasan terbentuknya matematika. Logika ibarat masa kecil (bayi) matematika, sementara matematika itu sendiri pada dasarnya ialah masa dewasa logika (Mustamin, 2013). Matematika juga merupakan pembelajaran yang dapat mengembangkan teknologi (Mansur, Helsa, \& Kenedi, 2017)

Matematika dalam pandangan Ruseffendi dalam Musdalifah (2016) ialah simbol, pengetahuan deduktif yang tidak menganggap pembuktian dengan cara induktif, pengetahuan mengenai pola keberaturan, struktur yang terorganisasi mulai unsur yang tak terdefenisi, lalu ke unsur yang terdefinisi, kemudian aksioma/postulat, hingga ke dalil. Kemudian Maarif (2015) juga mengungkapkan bahwa beberapa simbol pada matematika masih tidak punya arti, sehingga bisa diberi arti dari simbol-simbol tersebut yang sesuai lingkup serta semestanya. Dari sini bisa diputuskan bahwa hakikat matematika ialah cabang pengetahuan yang belajar tentang simbol, bahasa, postulat, serta penalaran logis yang mempunyai struktur terorganisasi.

Berdasarkan fakta yang ada pada lokasi penelitian, pelajaran matematika termasuk pelajaran yang begitu dihindari para peserta didik karena dianggap pelajaran yang rumit 
dipahami sekaligus membosankan untuk mereka. Selanjutnya Hidayati (2017) mengungkapkan bahwa anggapan negatif peserta didik terhadap matematika berefek pada hasil belajar matematika mereka. Hal ini pun serupa dengan pemaparan Mandailina dan Mahsup (2018) bahwa banyaknya peserta didik beranggapan matematika sebagai mata pelajaran yang rumit dimengerti, menjadikan perolehan skor hasil belajar mereka rendah (di bawah KKM: Kriteria Ketuntasan Minimal).

Hasil belajar sudah termasuk kepiawaian, pengetahuan, ataukah sikap peserta didik yang perlu berkembang sebagai hasil dari usaha belajar mereka (Biggs \& Tang, 2011; Kumpas-Lenk, Eisenschmidt, \& Veispak, 2018). Menurut Nugraha, Sudiatmi, dan Suswandari (2020) hasil belajar diartikan dengan kepiawaian peserta didik yang diraih setelah melakukan kegiatan pembelajaran. Menurut Malmia, dkk (2019) peningkatan hasil belajar para peserta didik bisa disebabkan beberapa faktor, diantaranya kegiatan belajar yang berpusat pada sosok pendidik. Proses belajar yang lebih didominasi sosok pendidik menjadikan peserta didik terlihat pasif selama proses pembelajaran. Hal ini mengakibatkan rangkaian pembelajaran menjadi tidak optimal dan tidak memberi ruang kesempatan bagi peserta didik untuk berpikir kritis dan berperilaku kreatif (Ernawati \& Lestari, 2020).

Pada rangkaian pendidikan, matematika diajarkan sejak jenjang SD sampai pada lingkup perguruan tinggi. Pembelajaran ini memang urgen diberikan pada peserta didik sejak kecil untuk membekalinya agar dapat berpikir kreatif, menalar, dan bekerja keras. Sikap positif terhadap matematika yang terbentuk sejak awal akan menjadi faktor penting terhadap kesuksesan belajar pada mata pelajaran tersebut, khususnya matematika (Siregar, 2017). Akan tetapi dalam kenyataannya, masih ada saja bahkan banyak yang menilai matematika sebagai pelajaran rumit, diantaranya saat mengerjakan soal yang disajikan dalam format cerita ataupun bukan.

Menurut Minarti (2013) soal dengan format cerita memuat soal-soal yang menerapkan Bahasa verbal yang banyak berkaitan dengan kehidupan nyata. Kepiawaian peserta didik saat mengerjakan soal cerita dapat dibuktikan dari perolehan hasil belajarnya. Bukan hanya itu, bisa juga dilihat dari setiap langkah mereka mengerjakan soal hingga mendapatkan jawaban benar (Nafi'an, 2011). Ketika mengerjakan soal cerita, peserta didik bukan hanya dituntut mempunyai kepiawaian berhitung, tapi memperhatikan proses penyelesaiannya juga (Utami, Edaryono, \& Djuhartono, 2018).

Soal yang disajikan dalam bentuk cerita terkait dengan permasalahan atau hal-hal yang lumrah terjadi pada kehidupan. Mayoritas para peserta didik akan mengalami kesulitan untuk mengerjakan bahkan menyelesaikan soal seperti ini, sebab untuk mengerjakannya mereka harus paham apa yang dimaksud oleh soal tersebut, apa yang ditanyakan, serta kesulitannya menentukan rumus yang digunakan. Penyebabnya karena ketika mengerjakan soal matematika berupa cerita, diperlukan langkah-langkah pemahaman dan nalar yang mumpuni. Tidak hanya itu, banyak juga peserta didik yang masih kurang paham menerjemahkan redaksi kalimat ke dalam model matematika. Karena itu, keterampilan para peserta didik dalam hal mengerjakan soal baik yang berbentuk cerita maupun bukan memerlukan beberapa keterampilan diantaranya memahami isi soal, membuat model matematika soal, kemudian perhitungan. Apabila salah satu dari 3 langkah ini mengalami kesalahan, maka peserta didik akan mengalami kesulitan untuk menyelesaikan soal. 
Berdasarkan hasil wawancara pada salah satu guru matematika dari MTs Negeri Sinjai Utara, beliau menjelaskan bahwa memang jumlah peserta didik yang kurang paham saat mengerjakan soal masih terbilang banyak, keadaan ini terjadi karena masih banyak yang tidak tahu atau tidak paham maksud dari soal, sehingga mereka sulit menerjemahkannya ke dalam model matematika. Selain itu, beliau juga menuturkan bahwa pada saat ujian, soal matematika yang berupa cerita termasuk dalam golongan soal yang rumit.

Pada pembelajaran soal cerita, guru/pendidik sebaiknya menggunakan Metode Polya agar peserta didik mempunyai keterampilan dan mampu menyelesaikan soal cerita agar hasil belajar mereka mengalami peningkatan juga. Penjelasan ini sejalan dengan langkah-langkah Metode Polya dalam penyelesaian soal matematika. Polya merupakan seorang matematikawan pada abad 20, dimana Polya terkenal dengan empat langkahnya dalam menyelesaikan masalah (Ariani \& Kenedi, 2018). Hal tersebut juga diungkapkan oleh Pardue, dkk (2020) yang mengemukakan bahwa Metode Polya terdiri dari empat langkah yang diekspresikan dalam bentuk pertanyaan meliputi: "What is the unknown? What are the data? What is the conditions?", dimana pertanyaan-pertanyaan tersebut dikelompokkan menjadi empat prosedur yakni: paham akan masalah, penyusunan strategi, pelaksanaan strategi, review, dan evaluasi.

Hasil beberapa penelitian sebelumnya menunjukkan bahwa penerapan Metode Polya dalam pembelajaran memiliki pengaruh yang cukup signifikan terhadap hasil belajar. Penelitian yang dilakukan Ayustina dan Ahmad (2020) menemukan bahwa terdapat dampak yang cukup baik dalam penerapan Model Polya pada hasil belajar peserta didik khususnya untuk soal cerita materi FPB-KPK (Faktor Persekutuan Terbesar-Faktor Persekutuan Terkecil) dengan rerata nilai 74 (grup kontrol) dan 85,39 (grup eksperimen). Selanjutnya, Nasution (2018) dalam penelitiannya menyimpulkan ada dampak dari strategi pemecahan masalah dengan Model Polya pada hasil belajar peserta didik. Wilanda dan Ahmad (2020) dalam penelitiannya juga menyatakan bahwa dampak dari penggunaan Model Polya cukup signifikan pada hasil belajar dalam soal cerita volume bangun ruang.

Berdasarkan beberapa hasil penelitian tersebut, penerapan Metode Polya dalam pembelajaran dapat menjadi solusi alternatif untuk mengatasi kesulitan peserta didik khususnya dalam menyelesaikan soal cerita pada pembelajaran matematika yang pada penjelasan sebelumnya dianggap rumit oleh sebagian besar peserta didik. Dari uraian latar belakang dan beberapa hasil penelitian tersebut maka penelitian lebih lanjut terkait hal ini menarik untuk dilakukan sehingga dapat diketahui dengan jelas perbedaan hasil belajar matematika peserta didik khususnya dalam menyelesaikan soal cerita melalui penerapan Metode Polya dalam proses pembelajaran.

\section{METODE PENELITIAN}

Penelitian ini menerapkan pendekatan kuantitatif, dan masuk dalam kelompok penelitian Quasi Experimental Design di mana peneliti menggunakan tepat 2 grup yaitu grup eksperimen $_{1}$ dan grup eksperimen ${ }_{2}$. Tujuan diselenggarakannya penelitian ini untuk mengetahui keefektifan penerapan Metode Polya saat mengerjakan soal matematika yang berbantuan soal cerita maupun tidak.

Desain penelitian menerapkan pola the nonequivalent control group design. Pada

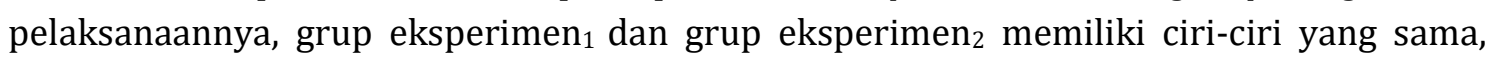


minimal mendekati sama. Ada perbedaan utama dari kedua grup ini, yakni kelompok

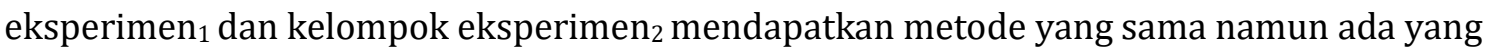
mengaplikasikan Metode Polya dan ada yang tidak.

Umumnya penelitian eksperimen dimodelkan sebagai berikut (Sugiyono, 2015):

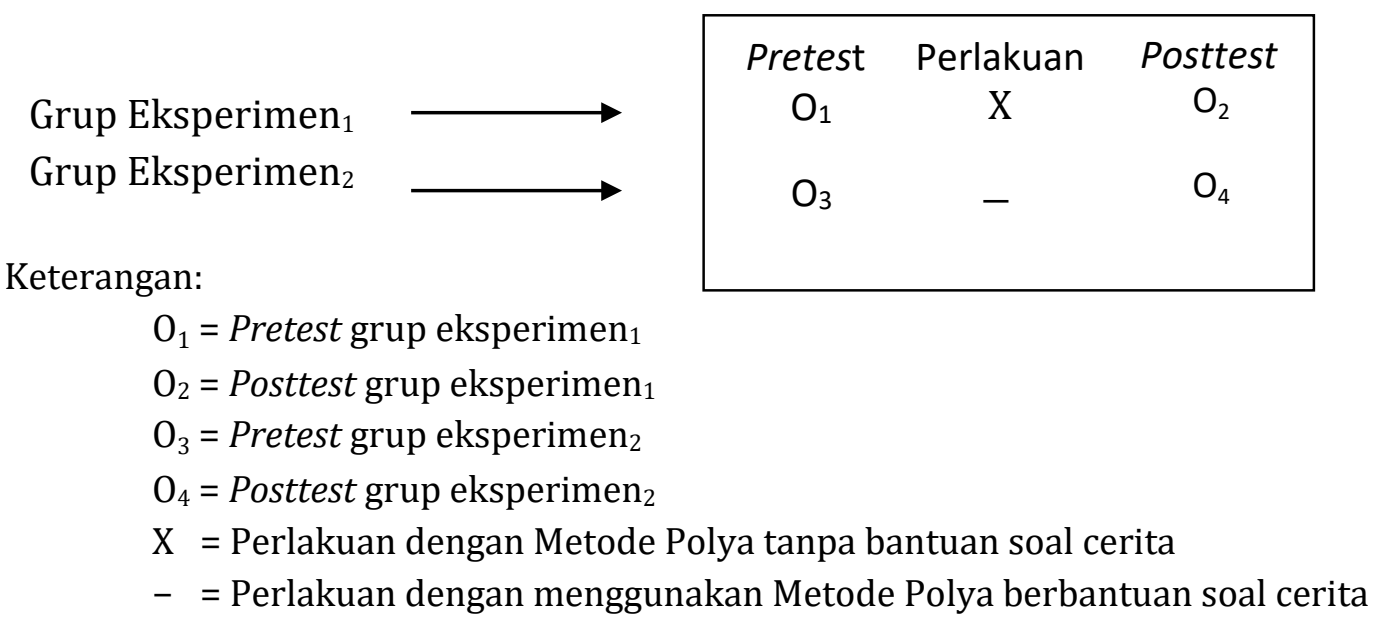

Penyelenggaraan penelitian dilakukan di MTs Negeri Sinjai Utara yang berlokasi di Jln. Slamet Riyadi, Sinjai Utara. Populasi pada penelitian ini ialah mereka dari kelas VIII $_{\mathrm{A}}$, $\mathrm{VIII}_{\mathrm{B}}, \mathrm{VIII}_{\mathrm{C}}, \mathrm{VIII}_{\mathrm{D}}$, hingga kelas $\mathrm{VIII}_{\mathrm{E}}$ dengan jumlah keseluruhan 152 peserta didik. Teknik pengambilan sampel yang digunakan yaitu teknik Simple Random Sampling. Sampel yang terpilih ialah mereka (peserta didik) yang berada di kelas VIII $_{D}$ dan VIIIC.

Dari penelitian ini ada 2 variabel, yaitu variabel " $\mathrm{x}$ " (independent/bebas) dan variabel " $\mathrm{y}$ " (dependent/terikat).
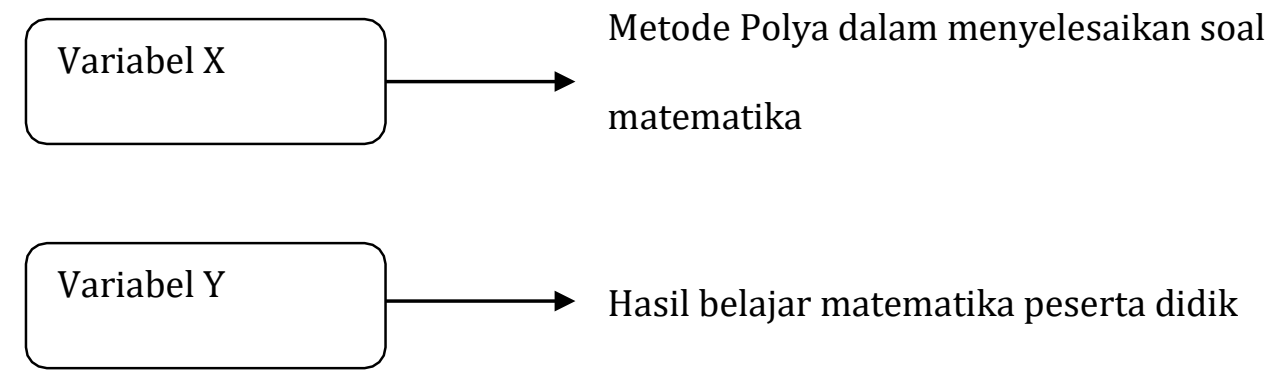

Cara untuk mengumpulkan data dilakukan dengan tes dan observasi. Karena metode ini, maka intrumen yang diterapkan ialah tes hasil belajar yang memuat 2 tes, tes pendahuluan (pretest) dan tes akhir (posttest).

Indikator untuk menginterprestasikan tingkatan validitas instrumen dilihat berdasarkan kriteria di bawah (Lestari \& Yudhanegara, 2015):

Tabel 1. Kriteria Koefisien Korelasi Validitas Instrumen

\begin{tabular}{ccc}
\hline Koefisien Korelasi & Korelasi & Interprestasi Validitas \\
\hline $0,90 \leq \mathrm{rxy} \leq 1,00$ & Sangat Tinggi & Sangat Tepat/Sangat Baik \\
$0,70 \leq \mathrm{rxy} \leq 0,90$ & Tinggi & Tepat/Baik \\
$0,40 \leq \mathrm{rxy} \leq 0,70$ & Sedang & Cukup Tepat/Cukup Baik \\
\hline
\end{tabular}




\begin{tabular}{ccc}
$0,20 \leq \mathrm{r}_{\mathrm{xy}} \leq 0,40$ & Rendah & Tidak Tepat/Buruk \\
$\mathrm{r}_{\mathrm{xy}} \leq 0,20$ & Sangat Rendah & Sangat Tidak Tepat/Sangat Buruk \\
\hline
\end{tabular}

Indikator dalam menginterprestasikan tingkatan reliabilitas instrumen ditetapkan berdasarkan kriteria sebagai berikut (Lestari \& Yudhanegara, 2015):

Tabel 2. Kriteria Koefisien Korelasi Validitas Instrumen

\begin{tabular}{ccc}
\hline Koefisien Korelasi & Korelasi & Interprestasi Reliabilitas \\
\hline $0,90 \leq \mathrm{r} \leq 1,00$ & Sangat Tinggi & Sangat Tepat/Sangat Baik \\
$0,70 \leq \mathrm{r} \leq 0,90$ & Tinggi & Tepat/Baik \\
$0,40 \leq \mathrm{r} \leq 0,70$ & Sedang & Cukup Tepat/Cukup Baik \\
$0,20 \leq \mathrm{r} \leq 0,40$ & Rendah & Tidak Tepat/Buruk \\
$\mathrm{r} \leq 0,20$ & Sangat rendah & Sangat Tidak Tepat/Sangat Buruk \\
\hline
\end{tabular}

Data yang didapatkan akan dianalisi dengan statistik deskriptif dengan maksud mendeskripsikan keterlaksanaan Metode Polya saat mengerjakan soal cerita matematika sekaligus melihat hasil penerapan metode ini. Selanjutnya analisis statistik inferensial dengan menggunakan uji $t$-test Polled Varians bertujuan untuk mengetahui apakah efektif mengaplikasikan Metode Polya dalam soal cerita matematika maupun tidak.

\section{HASIL DAN PEMBAHASAN}

Penyelenggaraan penelitian ini yakni dengan menerapkan Metode Polya terhadap 2

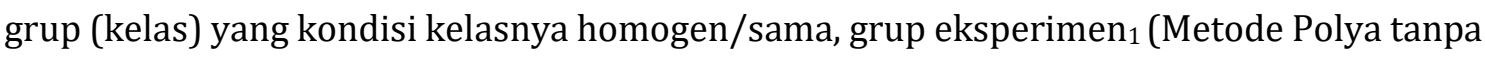
bantuan soal cerita) dan grup eksperimen 2 (Metode Polya bantuan soal cerita).

Hasil deskriptif pada kemampuan belajar peserta didik dalam kelas eksperimen ${ }_{1}$ setelah keterlaksanaan tes hasil belajar dengan menggunakan output SPSS.

Tabel 3. Deskripsi Hasil Belajar Matematika Peserta Didik Kelas Eksperimen

\begin{tabular}{lcccccc}
\hline & N & Minimum & Maximum & Mean & Std. Deviation & Variance \\
\hline Pretest_Eksperimen $_{1}$ & 30 & 35 & 65 & 50,77 & 8,748 & 76,530 \\
Posttest_Eksperimen $_{1}$ & 30 & 55 & 79 & 67,20 & 6,488 & 42,097 \\
Valid N (listwise) & 30 & & & & & \\
\hline
\end{tabular}

Dalam kelas eksperimen ${ }_{1}$ peneliti memberikan pretest sebanyak 6 item soal yang kemudian diberi perlakuan yakni menerapkan Metode Polya ketika mengajar tanpa soal cerita, selanjutnya diberi posttest yang juga sebanyak 6 item soal. Dari analisis secara statistik deskriptif, hasil pretest untuk grup eksperimen ${ }_{1}$ paling rendah mendapat skor 35 dan paling tinggi mendapat nilai 65 dan reratanya sebesar 50,77. Sementara hasil dari posttest pada kelas ini mendapat nilai terendah 55 dan nilai tertinggi 79 dan reratanya sebesar 67,20. Perolehan nilai ini menunjukkan bahwa terjadi perubahan yang baik pada hasil belajar para peserta didik karena ada peningkatan sebesar 16,43.

Apabila hasil belajar para peserta didik diterjemahkan dalam pengkategorian maka didapatkan frekuensi dan persentase ketika pretest dan posttest yang terlihat seperti pada gambar di bawah ini: 


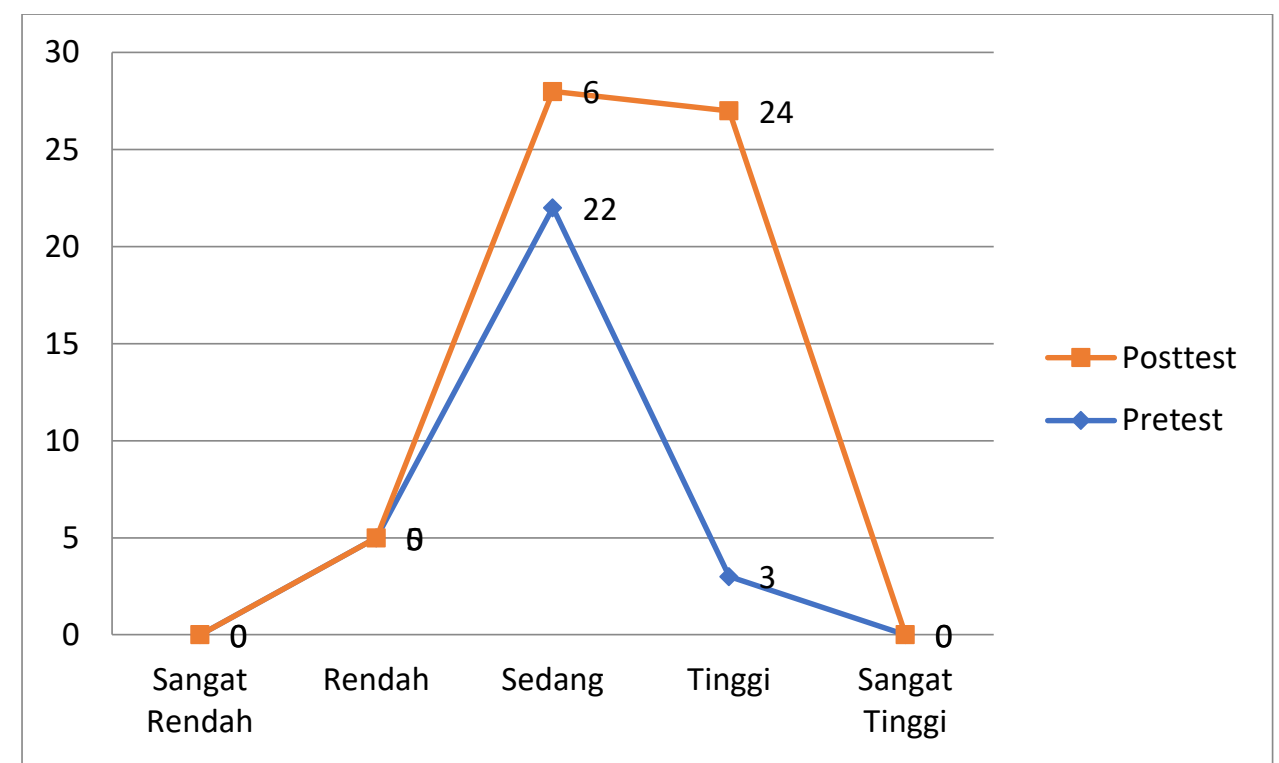

Gambar 1. Kategori Hasil Belajar Matematika Pretest dan Posttest Kelas Eksperimen

Dari informasi gambar tersebut, terlihat bahwa ketegori hasil belajar peserta didik yaitu: Ketika pretest tidak ada peserta didik dengan persentase $0 \%$ (sangat rendah), 5 termasuk kategori rendah (16,67\%), 22 masuk kategori sedang (73,33\%), 3 masuk kategori tinggi (10\%), dan tidak ada yang masuk kategori sangat tinggi (0\%). Sementara ketika posttest tidak ada yang masuk kategori sangat rendah dan rendah (0\%), 6 masuk kategori sedang (20\%), 24 termasuk kategori tinggi (80\%), dan masih tidak ada yang masuk kategori sangat tinggi $(0 \%)$.

Selanjutnya, hasil pengamatan untuk kelas eksperimen ${ }_{1}$ guna mengetahui rangkaian proses belajar para peserta didik.

Tabel 4. Data Hasil Observasi pada Kelas Eksperimen 1

\begin{tabular}{|c|c|c|c|c|}
\hline \multirow{2}{*}{ No } & \multirow{2}{*}{ Komponen Yang Diamati } & \multicolumn{3}{|c|}{ Pertemuan } \\
\hline & & I & II & III \\
\hline 1 & Peserta didik yang hadir pada saat pembelajaran & 30 & 30 & 29 \\
\hline 2 & Peserta didik yang fokus terhadap materi yang diajarkan & 30 & 30 & 29 \\
\hline 3 & $\begin{array}{l}\text { Peserta didik yang aktif pada saat diskusi dan pembahasan contoh } \\
\text { soal }\end{array}$ & 8 & 5 & 6 \\
\hline 4 & $\begin{array}{l}\text { Peserta didik yang menjawab pada saat diajukan pertanyaan tentang } \\
\text { materi yang diajarkan }\end{array}$ & 5 & 4 & 5 \\
\hline 5 & $\begin{array}{l}\text { Peserta didik yang bertanya kepada teman atau guru terkait materi } \\
\text { yang belum dimengerti }\end{array}$ & 8 & 5 & 4 \\
\hline 6 & $\begin{array}{l}\text { Peserta didik yang mengajukan diri untuk mengerjakan soal di papan } \\
\text { tulis }\end{array}$ & 4 & 4 & 7 \\
\hline 7 & Peserta didik yang aktif pada saat kerja menyelesaikan LKS & 30 & 28 & 30 \\
\hline 8 & $\begin{array}{l}\text { Peserta didik yang melakukan kegiatan lain pada saat proses } \\
\text { pembelajaran berlangsung }\end{array}$ & 5 & 4 & 2 \\
\hline 9 & Peserta didik yang masih perlu bimbingan dalam mengerjakan soal & 10 & 5 & 4 \\
\hline 10 & $\begin{array}{l}\text { Peserta didik yang bekerja sesuai dengan arahan guru untuk } \\
\text { menggali informasi tentang materi yang dibahas }\end{array}$ & 4 & 3 & 3 \\
\hline
\end{tabular}


Dari hasil lembar pengamatan untuk tatap muka pertama ada 30 peserta didik yang hadir, dari 10 komponen pengamatan ada 10 peserta didik yang masih membutuhkan arahan untuk menyelesaikan soal. Selanjutnya di pertemuan kedua masih terdapat 5 peserta didik yang membutuhkan bimbingan. Lalu dalam tatap muka ketiga dari 29 peserta didik yang hadir, rerata dari 10 bagian pengamatan, peserta didik membutuhkan arahan semakin berkurang.

Hasil analisis deskriptif data hasil belajar peserta didik untuk kelas eksperimen ${ }_{2}$ setelah diadakan tes menggunakan output dari SPSS.

Tabel 5. Deskripsi Hasil Belajar Matematika Peserta Didik Kelas Eksperimen 2

\begin{tabular}{lcccccc}
\hline & \multicolumn{1}{c}{ N } & Minimum & Maximum & Mean & Std. Deviation & Variance \\
\hline Pretest_Eksperimen $_{2}$ & 31 & 30 & 65 & 48,97 & 9,496 & 90,166 \\
Posttest_Eksperimen $_{2}$ & 31 & 55 & 90 & 69,29 & 9,403 & 88,413 \\
Valid N (listwise) & 31 & & & & & \\
\hline
\end{tabular}

Dari hasil analisis secara deskriptif diperoleh hasil pretest untuk kelas ini yang paling rendah ialah 30 dan paling tinggi adalah 65 dan reratanya sebesar 48,97. Sementara hasil posttest nilai terendah yang ada adalah 55 dan tertinggi 90 dengan rerata sebesar 69,29. Perolehan nilai-nilai ini membuktikan ada perubahan yang baik karena terjadi peningkatan sebesar 20,32.

Apabila hasil belajar peserta didik diklasifikasikan dalam pengkategorian, maka didapatkan nilai frekuensi dan persentase setelah pretest dan posttest sebagai berikut:

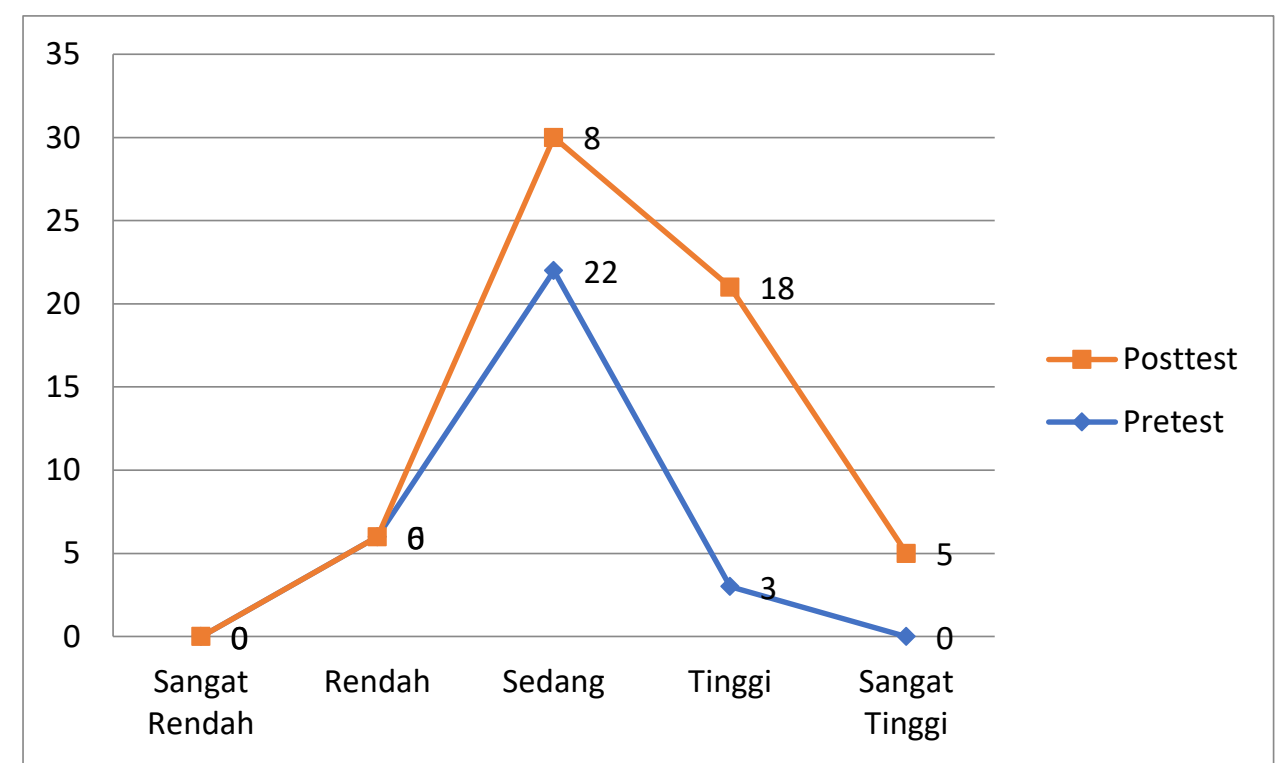

Gambar 2. Kategori Hasil Belajar Matematika Pretest dan Posttest Kelas Eksperimen 2

Berdasarkan gambar 2, terlihat jelas tingkat penguasaan materi pada pretest dan posttest yaitu: Pada pretest terdapat 0 peserta didik dengan persentase $0 \%$ pada kategori sangat rendah, 6 peserta didik dengan persentase 19,35\% yang termasuk dalam kategori rendah, 22 peserta didik dengan persentase 70, 97\% pada kategori sedang, 3 peserta didik dengan persentase $9,68 \%$ pada kategori tinggi dan 0 peserta didik dengan persentase $0 \%$ pada kategori sangat tinggi. Sedangkan pada posttest terdapat 0 peserta didik dengan 
persentase $0 \%$ pada kategori sangat rendah, 0 peserta didik dengan persentase $0 \%$ pada kategori rendah, 8 peserta didik dengan persentase 25,81\% pada kategori sedang, 18 peserta didik dengan persentase 58,96\% berada pada kategori tinggi, dan 5 peserta didik dengan persentase $16,13 \%$ berada pada kategori sangat tinggi.

Data dari kelas eksperimen2 saat kegiatan pembelajaran menerapkan Metode Polya berbantuan soal cerita dapat dilihat pada tabel berikut:

Tabel 6. Data Hasil Observasi pada Kelas Eksperimen 2

\begin{tabular}{|c|c|c|c|c|}
\hline \multirow{2}{*}{ No } & \multirow{2}{*}{ Komponen Yang Diamati } & \multicolumn{3}{|c|}{ Pertemuan } \\
\hline & & $\bar{I}$ & II & III \\
\hline 1 & Peserta didik yang hadir pada saat pembelajaran & 31 & 28 & 31 \\
\hline 2 & Peserta didik yang fokus terhadap materi yang diajarkan & 31 & 28 & 31 \\
\hline 3 & $\begin{array}{l}\text { Peserta didik yang aktif pada saat diskusi dan pembahasan contoh } \\
\text { soal }\end{array}$ & 6 & 4 & 7 \\
\hline 4 & $\begin{array}{l}\text { Peserta didik yang menjawab pada saat diajukan pertanyaan tentang } \\
\text { materi yang diajarkan }\end{array}$ & 4 & 3 & 2 \\
\hline 5 & $\begin{array}{l}\text { Peserta didik yang bertanya kepada teman atau guru terkait materi } \\
\text { yang belum dimengerti }\end{array}$ & 3 & 6 & 2 \\
\hline 6 & $\begin{array}{l}\text { Peserta didik yang mengajukan diri untuk mengerjakan soal di papan } \\
\text { tulis }\end{array}$ & 6 & 3 & 4 \\
\hline 7 & Peserta didik yang aktif pada saat kerja menyelesaikan LKS & 31 & 26 & 31 \\
\hline 8 & $\begin{array}{l}\text { Peserta didik yang melakukan kegiatan lain pada saat proses } \\
\text { pembelajaran berlangsung }\end{array}$ & 2 & 0 & 2 \\
\hline 9 & Peserta didik yang masih perlu bimbingan dalam mengerjakan soal & 8 & 5 & 2 \\
\hline 10 & $\begin{array}{l}\text { Peserta didik yang bekerja sesuai dengan arahan guru untuk menggali } \\
\text { informasi tentang materi yang dibahas }\end{array}$ & 5 & 6 & 3 \\
\hline
\end{tabular}

Dari hasil lembar observasi tatap muka pertama dari 31 peserta didik yang hadir terlihat bahwa dari 10 komponen yang diamati terdapat 8 peserta didik yang masih membutuhkan bimbingan saat mengerjakan soal, pada tatap muka kedua peserta didik yang masih membutuhkan bimbingan dalam mengerjakan berkurang menjadi 5 , dan pada tatap muka ketiga dari 31 peserta didik, rata-rata 10 komponen yang diamati oleh peserta didik yang masih memerlukan arahan saat mengerjakan soal semakin mengecil.

Dari hasil penelitian, terjadi peningkatan pencapaian belajar peserta didik dalam kelas eksperimen 1 dan 2. Peningkatan pencapaian pembelajaran dalam kelas eksperimen 1 dan 2 karena kemampuan peserta didik ketika menyelesaikan soal baik soal cerita ataupun bukan semakin membaik. Hal ini disebabkan karena melalui tahapan pemecahan masalah Metode Polya yang lebih sistematis dan akan memudahkan peserta didik menyelesaikan soal yang ada. Hal ini sesuai teori pengkondisian Pavlov, ia mengatakan bahwa belajar adalah usaha mengkondisikan membentuk tingkah laku (Rusuli, 2014). Teori ini menyatakan peserta didik bisa belajar dengan baik, mereka harus membiasakan diri. Misal, tiap belajar matematika, peserta didik berlatih baik soal cerita maupun yang bukan dengan menggunakan pemecahan masalah menurut Polya, sehingga sendirinya ia terbiasa memakai alur Metode Polya saat menyelesaikan masalah. 
Hasil pretest dan posttest kedua kelas kemudian akan diuji normalitas, uji homogenitas, dan uji hipotesis. Dari uji normalitas dan uji homogenitas menunjukkan kedua kelas berdistribusi normal dan homogen.

Uji t diterapkan untuk menganalisis hipotesis penelitian. Hal ini bermaksud agar peneliti mengetahui ada atau tidaknya perbedaan Metode Polya tanpa bantuan soal cerita dengan Metode Polya yang dibantu soal cerita terhadap pencapaian hasil pembelajaran peserta didik. Oleh sebab itu, hipotesis secara statistik dirumuskan:

$H_{0}$ : Tidak ada perbedaan rerata hasil belajar antara peserta didik yang diterapkan Metode Polya dibantu soal cerita dengan Metode Polya tanpa dibantu soal cerita $H_{1}$ : Ada perbedaan rerata hasil belajar peserta didik yang diterapkan Metode Polya dibantu soal cerita dengan Metode Polya tanpa dibantu soal cerita

Tabel 7. Hasil Uji Independent Samples Test

\begin{tabular}{|c|c|c|c|c|c|c|c|c|}
\hline & $\begin{array}{r}\text { Lev } \\
\text { Tes } \\
\text { Equa } \\
\text { Vari }\end{array}$ & $\begin{array}{l}\text { ene's } \\
\text { t for } \\
\text { lity of } \\
\text { ances } \\
\end{array}$ & & & $t$-test $f$ & for Equality & of Means & \\
\hline & $\mathbf{F}$ & Sig. & $\mathbf{T}$ & df & $\begin{array}{l}\text { Sig. (2- } \\
\text { tailed) }\end{array}$ & $\begin{array}{c}\text { Mean } \\
\text { Difference }\end{array}$ & $\begin{array}{l}\text { Std. Error } \\
\text { Difference }\end{array}$ & $\begin{array}{c}95 \% \\
\text { Confidence } \\
\text { Interval of } \\
\text { the } \\
\text { Difference } \\
\end{array}$ \\
\hline & & & & & & & & Lower Upper \\
\hline $\begin{array}{l}\text { Nilai Equal } \\
\text { variances } \\
\text { assumed }\end{array}$ & 3,403 & , 070 & $-1,007$ & 59 & 318 & $-2,090$ & 2,075 & $-6,2432,062$ \\
\hline $\begin{array}{l}\text { Equal } \\
\text { variances } \\
\text { not } \\
\text { assumed }\end{array}$ & & & $-1,013$ & 53,408 & 315 & $-2,090$ & 2,063 & $-6,227 \quad 2,046$ \\
\hline
\end{tabular}

Pengujian dengan teknik independent sample test pada taraf $\operatorname{sig} \alpha=5 \%$. Dari hasil perhitungan menggunakan SPSS didapatkan nilai sig sebesar 0,318, perolehan nilai ini menggambarkan bahwa $H_{0}$ diterima, berarti $H_{1}$ ditolak. Penolakan $H_{1}$ karena nilai sig $>\alpha$ : $0,318>0,05$. Maka dapat dikatakan tidak ada perbedaan pada hasil belajar peserta didik yang menggunakan model Polya dibantu soal cerita dan tidak dibantu soal cerita.

Dari perolehan percobaan, perubahan pencapaian pembelajaran untuk kelas eksperimen $_{1}$ naik sebesar 16,43 . Sementara untuk kelas eksperimen ${ }_{2}$ naik 20,32 . Perbedaan nilai rerata yang terjadi pada kedua kelas tersebut sebanyak 3,89 , dalam hal ini kelas eksperimen $_{2}$ lebih unggul dari kelas eksperimen ${ }_{1}$, jadi hal ini memungkinkan peneliti untuk menyimak perbedaan hasil belajar yang terjadi pada kedua kelas. Setelah hipotesis diuji, maka diputuskan bahwa tidak ada perbedaan pada rerata pencapaian pembelajaran peserta didik yang menerapkan mekanisme Polya berbantuan soal cerita dengan Metode Polya tanpa dibantu soal cerita. Dari pengujian secara deskriptif dan juga inferensial bisa disebut bahwa perbedaan hasil belajar ini tidak signifikan yaitu hanya sebesar 3,89. 
Setelah pengolahan data maka dapat diketahui bahwa tidak adanya perbedaan hasil belajar pada kedua kelas yang diambil disebabkan oleh beberapa hal, yakni:

1. Kepiawaian tiap peserta didik dalam memahami masalah tidaklah sama

2. Karena penyebab dari poin pertama di atas, peserta didik menjadi kesulitan dalam membuat rumus matematika soal

3. Kurang tepatnya para peserta didik saat menyelesaikan soal

Pada pembelajaran matematika, Metode Polya tidak berbeda dengan metode pemecahan masalah yang lain, sama-sama mempunyai karakteristik dan sintaks yang menunjang agar pemecahan masalah dari peserta didik dapat meningkat. Hanya saja nilai tambah dari Metode Polya dalam pembelajaran matematika ialah sintaksnya yang lebih sistematis dan membiasakan serta mendorong peserta didik agar menganalisis sekaligus mengerjakan soal dengan terampil. Hal ini juga didukung oleh penelitian yang dilakukan oleh (Rudtin, 2013) dengan judul penerapan langkah Polya dalam Model Problem Based Instruction untuk meningkatkan kemampuan siswa menyelesaikan soal cerita yang hasil penelitiannya menemukan bahwa pembelajaran yang menggunakan langkah Polya dalam Model Problem Based Instruction tersebut dapat meningkatkan kemampuan siswa pada penyelesaian soal cerita persegi panjang di Kelas VII SMP Negeri 7 Palu. Selain itu metode ini dapat menstimulus perkembangan keterampilan berpikir dari peserta didik dengan kreatif serta komprehensif, sebab saat kegiatan pembelajaran terdapat banyak peserta didik berpikir dengan cara melihat permasalahan untuk menemukan solusi dari permasalahan tersebut. Sejalan dengan hal ini, (Komariah, 2011) dalam penelitiannya juga mengemukakan bahwa langkah-langkah pemecahan masalah Model Polya dapat membimbing kreativitas peserta didik dalam menyelesaikan masalah secara ilmiah. Hal ini memotivasi peserta didik untuk dapat belajar secara mandiri dan melatih untuk berpikir logis dan teliti sehingga kesalahan dalam proses menyelesaikan masalah terkontrol dengan dilakukannya looking back terhadap langkah-langkah yang telah dilakukan.

Kelemahan dari Metode Polya ialah proses belajarnya yang memerlukan waktu cukup lama. Meski memiliki kekurangan, bukan berarti Metode Polya kurang efektif untuk diterapkan. Metode ini efektif terbukti dari perolehan nilai pretest dan posttest yang diperoleh setelah uji coba, di mana dua kelas peserta didik yang dijadikan sebagai uji coba mengalami peningkatan pada hasil belajar mereka.

\section{SIMPULAN}

Dari rangkaian penelitian yang telah dilakukan, diperoleh informasi di mana hasil

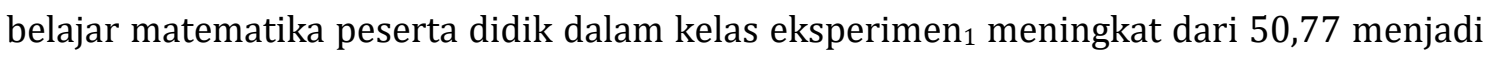
67,20 , demikian juga pada kelas eksperimen ${ }_{2}$ yang hasil belajar matematika peserta didiknya mengalami peningkatan yakni dari 48,97 menjadi 69,29. Perolehan data dari kedua kelas ini terlihat bahwa tidak ada variasi rerata pencapaian pembelajaran peserta didik antara menerapkan Metode Polya baik yang berbantuan atau pun tidak dibantu soal cerita. Hal ini disebabkan karena pada dasarnya Metode Polya tidak jauh berbeda dengan metode pemecahan masalah yang lain, yaitu mempunyai karakteristik dan sintaks yang menunjang agar pemecahan masalah dari peserta didik dapat meningkat. Namun kelebihan lain dari Metode Polya dalam pembelajaran matematika ialah sintaksnya yang lebih sistematis dan membiasakan serta mendorong peserta didik agar menganalisis sekaligus 
mengerjakan soal dengan terampil. Selain itu, keefektifan penggunaan Metode Polya juga terbukti karena hasil belajar matematika peserta didik di kedua kelas eksperimen mengalami perubahan nilai menjadi lebih baik.

\section{DAFTAR PUSTAKA}

Ariani, Y., \& Kenedi, A. K. (2018). Model Polya dalam peningkatan hasil belajar matematika pada pembelajaran soal cerita volume di sekolah dasar. Jurnal Inspirasi Pendidikan, 8(2), 25-36. https://doi.org/10.21067/jip.v8i2.2520

Ayustina, S., \& Ahmad, S. (2020). Pengaruh model Polya terhadap hasil belajar soal cerita di sekolah dasar. Jurnal Pendidikan Tambusai, 4(3), 2768-2778. https://doi.org/10.31004/jptam.v4i3.772

Biggs, J., \& Tang, C. (2011). Teaching for quality learning at university: What The Student Does (4th ed.). McGraw-Hill Education.

Ernawati, E., \& Lestari, P. (2020). Efektivitas metode problem solving dengan model Polya terhadap hasil belajar peserta didik dalam menyelesaikan soal cerita matematika. Equals, 3(1), 50-62. https://doi.org/10.46918/eq.v3i1.582

Hasbullah. (2012). Dasar-dasar ilmu pendidikan (X). Rajawali Press.

Hidayati, N. (2017). Efektivitas pembelajaran menggunakan multimedia interaktif (adobe flash CS6) terhadap hasil belajar matematika siswa kelas V SDN Jurug Sewon. TRIHAYU: Jurnal Pendidikan, 3(3). https://doi.org/dx.doi.org/10.30738/trihayu.v3i3.1883

Husnidar. (2020). Meningkatkan kemampuan pemecahan masalah siswa melalui model pembelajaran glasser pada materi bangun ruang sisi datar di SMP N 1 Samalanga. ASIMETRIS: Jurnal Pendidikan Matematika Dan Sains, 1(2), 57-63.

Ihsan, F. (2011). Dasar-dasar kependidikan (VII). Rineka Cipta.

Komariah, K. (2011). Penerapan metode pembelajaran problem solving model Polya untuk meningkatkan kemampuan memecahkan masalah bagi siswa kelas IX J di SMPN 3 Cimahi. Prosiding Seminar Nasional Penelitian, Pendidikan Dan Penerapan MIPA, Fakultas MIPA, Universitas Negeri Yogyakarta, 1.

Kumpas-Lenk, K., Eisenschmidt, E., \& Veispak, A. (2018). Does the design of learning outcomes matter from students' perspective? studies in educational evaluation, 59, 179-186. https://doi.org/10.1016/j.stueduc.2018.07.008

Lestari, K. E., \& Yudhanegara, M. R. (2015). Penelitian pendidikan matematika (I). PT Refika Aditama.

Maarif, S. (2015). Integrasi matematika dan Islam dalam pembelajaran matematika. Infinity, Jurnal Ilmiah Program Studi Matematika STKIP Siliwangi, 4(2), 223-236. https://doi.org/10.22460/infinity.v4i2.p223-236

Malmia, W., Makatita, S. H., Lisaholit, S., Azwan, Magfirah, I., Tinggapi, H., Chairul, M., \& Umanailo, B. (2019). Problem-based learning as an effort to improve student learning outcomes. International Journal of Scientific \& Technology Research, 8(9), 1140-1143.

Mandailina, V., \& Mahsup. (2018). Efektivitas pembelajaran matematika dengan metode Thinking Aloud Pair Problem Solving (TAPPS) terhadap hasil belajar siswa pokok bahasan kubus dan balok kelas VIII SMP/MTs. JTAM (Jurnal Teori Dan Aplikasi Matematika), 2(2), 144-147. https://doi.org/10.31764/jtam.v2i2.717 
Mansur, Helsa, Y., \& Kenedi, A. K. (2017). Al-Quran based learning strategy in teaching mathematics at primary education. Proceedings of the International Conference of Early Childhood Education (ICECE 2017), 304-306. https://doi.org/10.2991/icece17.2018.78

Minarti. (2013). Analisis tingkat kemampuan siswa dalam memecahkan masalah bentuk soal cerita pada materi sistem persamaan liner dua variabel. Jurnal FMIPA Universitas Negeri Surabaya, 2.

Musdalifah, R. A. (2016). Analisis kesalahan peserta didik dalam menyelesaikan soal trigonometri dengan panduan kriteria Polya kelas XI SMA Negeri 1 Sigeri Kabupaten Pangkep. Universitas Islam Alauddin Makassar.

Mustamin, S. H. (2013). Psikologi pembelajaran matematika (I). Alauddin University Press.

Nafi'an, M. I. (2011). Kemampuan siswa dalam menyelesaikan soal cerita ditinjau dari gender di sekolah dasar. In Matematika dan Pendidikan Karakter dalam Pembelajaran.

Nasution, H. A. (2018). Pengaruh strategi pemecahan masalah polya terhadap hasil belajar matematika siswa. Jurnal Penelitian Pendidikan MIPA, 3(1), 197-201.

Nugraha, S., Sudiatmi, T., \& Suswandari, M. (2020). Studi pengaruh daring learning terhadap hasil belajar matematika kelas IV. Jurnal Inovasi Penelitian, 1(3), 265-276. https://doi.org/10.47492/jip.v1i3.74

Pardue, J. H., Doran, M. V., \& Longenecker, H. E. (2020). Using Polya to teach system development methodologies: fostering a role perspective in IS students. Journal of Information Systems Education, 11(1), 67-72.

Retna, M. (2013). Proses Berfikir siswa dalam menyelesaikan soal cerita ditinjau berdasarkan kemampuan matematika. Jurnal Pendidikan Matematika STKIP PGRI Sidoarjo, 2.

Rudtin, N. A. (2013). Penerapan langkah Polya dalam model problem based instruction untuk meningkatkan kemampuan siswa menyelesaikan soal cerita. Jurnal Elektronik Pendidikan Matematika Tadulako, 01(01), 17-31.

Rusuli, I. (2014). Refleksi teori belajar behavioristik dalam perspektif Islam. Jurnal Pencerahan, 8(1), 38-54. https://doi.org/10.13170/jp.8.1.2041

Siregar, N. R. (2017). Persepsi siswa pada pelajaran matematika: studi pendahuluan pada siswa yang menyenangi game. Prosiding Temu Ilmiah X Ikatan Psikologi Perkembangan Indonesia, 1, 22-24.

Sugiyono. (2015). Metode penelitian pendidikan (pendekatan kuantitatif, kualitatif, dan $R \& D)(\mathrm{XXI})$. Alfabeta.

Utami, R. W., Endaryono, B. T., \& Djuhartono, T. (2018). Kemampuan peserta didik dalam menyelesaikan soal cerita matematik. Faktor Jurnal Ilmiah Kependidikan, 5(3), 187192. https://doi.org/dx.doi.org/10.30998/.v5i3.2719

Wilanda, K. N., \& Ahmad, S. (2020). Pengaruh penggunaan model Polya terhadap hasil belajar soal cerita di sekolah dasar. E-Journal Pembelajaran Inovasi, Jurnal Ilmiah Pendidikan Dasar, 8(4), 182-195. 